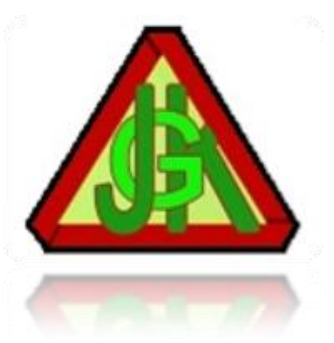

\title{
HUBUNGAN TINGKAT PENGETAHUAN REMAJA TENTANG COVID-19 DENGAN SIKAP REMAJA DALAM MENERAPKAN PROTOKOL KESEHATAN DI MASA PANDEMI COVID-19
}

\author{
Putu Maya Oktavianti ${ }^{1}$, N.L.K.Sulisnadewi ${ }^{2}$, Ida Erni Sipahutar ${ }^{3}$ \\ ${ }_{1,2,3}$ Politeknik Kesehatan Kemenkes Denpasar \\ Denpasar, Indonesia \\ e-mail:putumaya03@gmail.com ${ }^{1}$, dewisulisna@gmail.com², \\ ernii61@yahoo.com ${ }^{3}$
}

\begin{abstract}
Abstrak
COVID- 19 sudah berlangsung di seluruh dunia termasuk Indonesia. Pencegahan COVID- 19 bisa ditekan dengan tingkat pengetahuan yang baik serta sikap yang positif terhadap remaja. Penelitian ini bertujuan untuk mengetahui hubungan tingkat pengetahuan remaja tentang COVID-19 dengan sikap remaja dalam menerapkan protokol kesehatan di masa pandemi COVID-19. Jenis penelitian non-eksperimen dengan rancangan korelasional dan desain cross sectional. Penelitian ini sampel berjumlah 90 orang dengan menggunakan probabiility sampliing yaitu simpele random sampliing. Pengumpulan data menggunakan kuesioner melalui whatsapp dengan menggunakan google from. Hasil penelitian menunjukkan umur terbanyak ialah 13 tahun $(43,3 \%)$, jenis kelamin terbanyak ialah perempuan $(53,3 \%)$, tingkat pengetahuan remaja tentang COVID-19 berkategori baik $(88,9 \%)$ dan sikap remaja dalam menerapkan protokol kesehatan di masa pandemi COVID-19 berkategori positif $(84,4 \%)$. Uji hipotesis mengunakan spearman rank dengan nilai $\mathrm{p}=0,000(\alpha=0,05)$ dan nilai $\mathrm{r}=0,726$. Terdapat hubungan yang kuat, positif serta signifikan antara tingkat pengetahuan remaja tentang COVID-19 dengan sikap remaja dalam menerapkan protokol kesehatan di masa pandemi COVID-19. Responden diharapkan bisa memilah informasi yang tersebar tentang COVID-19 mana yang baik serta benar dan berasal dari sumber terpercaya, sehingga responden mengetahui dan dapat menerapkan protokol kesehatan dengan baik dan benar.
\end{abstract}

Kata kunci: tingkat pengetahuan; sikap; COVID-19; protokol kesehatan

\begin{abstract}
COVID-19 is already happening all over the world, including Indonesia. Prevention of COVID-19 can be suppressed with a good level of knowledge and a positive attitude towards youth. Study aims determine relationship between level of adolescent knowledge about COVID-19 with adolescent attitudes in implementing health protocols during COVID-19 pandemic.This type of research is nonexperimental with correlational draft and design cross sectional. The sample in this study amounted to 90 people using probability sampling techniques, namely
\end{abstract}


simple random sampling. Data was collected using questionnaire via whatsapp using google from. Results showed that highest age 13 years (43.3\%), highest gender female (53.3\%), level of adolescent knowledge about COVID-19 good $(88.9 \%)$ and attitude of adolescents in implementing health protocols during COVID-19 pandemic classified positive (84.4\%). Hypothesis testing used Spearman rank with value $p=0.000(\alpha=0.05)$ and value $r=0.726$. The is strong, positive and significant relationship between level of knowledge of adolescents about COVID-19 and attitude of adolescents in implementing health protocols during COVID-19 pandemic. Respondents are expected to able to sort information circulating about COVID-19 which is good and true and comes from trusted sources, so that respondents know and can apply health protocols properly and correctly.

Keywords: knowledge level; attitude; COVID-19; health protocol

\section{PENDAHULUAN}

Coronavirus Disease 2019 sudah berlangsung pada akhir bulan Desember 2019, di Kota Wuhan, Cina. Bertepatan 11 Februari 2020, World Health Organization mengumumkan secara resmi nama virus baru penyebab pneumonia dengan Severe Acute Respiratory Syndrome Coronavirus-2 (SARS-CoV-2) dan nama penyakit adalah Coronavirus Disease 2019 (COVID-19) ${ }^{(1)}$. Coronavirus ialah keluarga besar virus yang menyebabkan penyakit mulai dari gejala ringan sampai berat.

Peristiwa COVID-19 di dunia tiap hari terus meningkat. Berdasarkan data World Health Organization 12 Januari 2021 jumlah yang terkonfirmasi positif sebanyak 88.387.352 serta jumlah yang meninggal sebanyak 1.919.204. Amerika Serikat merupakan negara yang paling banyak terkonfirmasi positif COVID-19 dengan jumlah sebanyak 38.861.668 dan jumlah yang meninggal sebanyak $910.741^{(2)}$. Indonesia hingga tanggal 17 Januari 2021 jumlah COVID-19 yang terkonfirmasi positif sebanyak 907.929 serta jumlah yang meninggal sebanyak 25.987. Provinsi Bali jumlah COVID-19 yang terkonfirmasi positif sebanyak 21.444 dan jumlah yang meninggal sebanyak $591^{(3)}$. Data COVID-19 di Kota Denpasar yang terkonfirmasi positif sebanyak 5904 dan jumlah yang meninggal sebanyak 121. Kasus yang terjadi di kecamatan Denpasar Utara sebanyak $454^{(4)}$. 
Tidak hanya melanda orang dewasa, COVID-19 juga melanda anak-anak maupun remaja. Berdasarkan penelitian yang dilakukan oleh CDC Amerika Serikat 2020, sebanyak 2.572 terjadi pada anak usia <18 tahun, rata-rata usia adalah 11 tahun. Sebanyak 813 pada anak-anak berusia 15-17 tahun. 682 anakanak berusia 10-14 tahun, 398 pada anak-anak berusia <1 tahun, 291 pada anakanak berusia 1- 4 tahun, dan 388 pada anak-anak berusia 5-9 tahun ${ }^{(5)}$. Indonesia hingga tanggal 17 Januari 2021 sebanyak 2.7\% pada anak usia 0-5 tahun, sedangkan sebanyak 8.9\% pada anak usia 6-18 tahun. Provinsi Bali sebanyak 2.2\% pada anak usia 0-5 tahun, sedangkan sebanyak 7.8\% pada anak usia 6-18 $\operatorname{tahun}^{(3)}$.

Pengetahuan yang baik pada remaja tentang COVID-19 ialah perihal yang amat penting bagi remaja sehingga tidak memunculkan kenaikan jumlah kasus COVID-19. Dalam Penelitian ${ }^{(6)}$, sebanyak 30,65\% memiliki pengetahuan yang tidak baik tentang COVID-19. Survey yang dilakukan oleh UNICEF terhadap 4000 remaja terkait COVID-19 menunjukkan masih ada remaja (25\%) yang memiliki pengetahuan yang kurang tentang COVID-19 ${ }^{(7)}$. Pengetahuan remaja tentang COVID-19 memiliki peran yang penting dalam perubahan sikap ${ }^{(6)}$. Sikap adalah kesiapan seorang dalam berperan terhadap sesuatu objek dengan metode tertentu. Sikap remaja dalam merespon tiap keputusan pemerintah dalam memutus rantai penyebaran serta penularan COVID-19 amat penting. Penyebaran serta penularan COVID-19 dapat dicegah dengan pengetahuan serta sikap yang baik pada remaja. Remaja dianggap hampir dewasa sebab sudah mempunyai mental, sosial, emosional dan fisik yang matang, begitu pula dengan pemikirannya. Kematangan tersebut tentu saja tidak dibarengi oleh sikapnya. Dalam penelitian ditemukan bahwa sebanyak $29,3 \%$ responden masih memiliki sikap yang buruk terhadap penerapan protokol kesehatan COVID-19 dan 17\% masih memiliki pengetahuan yang buruk. Studi UNICEF Indonesia menyatakan bahwa di tengah pandemi COVID-19 sebanyak 40\% remaja masih memiliki sikap yang kurang dalam menerapkan protokol kesehatan dengan remaja masih berada di luar rumah tanpa menerapkan protokol kesehatan ${ }^{(8)}$. Pengetahuan yang baik tentu akan menghadirkan sikap yang baik, begitupun sebaliknya ${ }^{(6)}$. Penelitian ini bertujuan 
untuk mengetahui hubungan tingkat pengetahuan remaja tentang COVID-19 dengan sikap remaja dalam menerapkan protokol kesehatan di masa pandemi COVID-19.

\section{METODE}

Jenis penelitian non-eksperimen dengan rancangan korelasional dan desain penelitian cross-sectional $^{(9)}$. Penelitian dilaksanakan bulan Maret - April 2021. Responden yang digunakan siswa kelas VII dan VIII SMP Negeri 10 Denpasar sebanyak 90 responden. Adapun kriteria inklusi dan kriteria eksklusi pada penelitian ini sebagai berikut: kriteria inklusi yakni siswa kelas VII dan VIII SMP Negeri 10 Denpasar, siswa yang berumur 11-15 tahun, siswa yang bersedia mejadi responden, siswa yang memiliki aplikasi whatsapp. Kriteria eksklusi yakni siswa yang saat penelitian sakit, siswa yang saat penelitian izin, siswa yang saat penelitian tidak memiliki kuota internet. Teknik pengambilan sampel yang digunakan adalah simplee random sampling ${ }^{(9)}$.

Pengumpulan data menggunakan kuesioner pengetahuan dan kuesioner sikap yang dibuat sendiri oleh peneliti. Pengetahuan dinilai terdiri dari segala informasi yang diketahui oleh responden tentang COVID-19 yang meliputi definisi, cara penularan COVID-19, lama waktu yang diperlukan tertular hingga muncul gejala, gejala COVID-19 dan pencegahan COVID-19. Sikap dinilai sesuai dengan sikap remaja dalam menanggulangi COVID- 19. Pengukuran pertanyaan pengetahuan menggunakan skala Guttman $(\mathrm{ya}=$ skor 1 , dan tidak = skor 0$)$. Skala Guttman skor untuk pertanyaan positif ya (skor 1) dan tidak (skor 0) dan pertanyaan negatif adalah adalah ya (skor 0) dan tidak (skor 1). Skala Likert digunakan untuk pengukuran sikap, item-item disusun berupa pertanyaan positif dan negatif. Pernyataan positif untuk jawaban sangat setuju (skor 4), setuju (skor 3), tidak setuju (skor 2), sangat tidak setuju (skor 1). Sedangkan untuk pertanyaan negatif, jawaban sangat setuju (skor 1), setuju (skor 2), tidak setuju (skor 3), sangat tidak setuju (skor 4).

Validitas konstruk dan reliabiltias (internal konsistens) kuesioner pengetahuan dan sikap dilakuan terhadap 30 remaja di SMP Negeri 12 Denpasar. 
Hasil uji validitas keseluruhan pada kuesioner diperoleh rtabel $=0,374(\mathrm{df}=28)$ dengan sig 5\% (10). Nilai rhitung kuesioner pengetahuan remaja tentang COVID19, didapatkan 15 pertanyaan dinyatakan valid, kecuali nomor 3, 4, 5, 6, 9 dengan (rhitung $>0,374)$ dan nilai Cronbach's alpha $=0,739$. Nilai rhitung kuesioner sikap remaja dalam menerapkan protokol kesehatan di masa pandemi COVID-19 didapatkan 19 pertanyaan dinyatakan valid, pertanyaan nomor 15 tidak valid dengan (rhitung $>0,374$ ) dan nilai Cronbach's alpha $=0,755$. Uji reliabilitas kusioner pada penelitian > 0,60 maka kusioner dalam penelitian ini dinyatakan reliabel.

Data primer dan data sekunder merupakan data yang di kumpulkan pada penelitian ini. Data primer dikumpulkan dengan mengirimkan kuesioner melalui group whatsapp dengan menggunakan google form, sebelum mengirimkan kuesioner terlebih dahulu mengirimkan lembar persetujuan (informed consent) dan jika responden bersedia untuk diteliti maka responden bisa menandatangani lembar persetujuan dalam bentuk online menggunakan zoho form dengan cara mengirimkan lembar persetujuan dalam bentuk word, setelah itu memberitahu responden untuk membacanya terlebih dahulu isi dari lembar persetujuan, kemudian mengirimkan link tanda tangan menggunakan zoho form yang dikirim ke grup whatsapp .

Data sekunder yang dikumpulan dalam penelitian ini adalah gambaran umur serta jumlah siswa SMP Negeri 10 Denpasar. Analisis univariat dan bivariat merupakan analisis data yang digunakan pada penelitian ini. Data umur, jenis kelamin, tingkat pengetahuan remaja tentang COVID, sikap remaja dalam menrapkan protokol kesehatan di masa pandemi COVID-19 dianalisis dengan analisis univariat. Analisi bivariat dilakukan untuk menganalisi hubungan antara tingkat pengetahuan remaja tentang COVID dengan sikap remaja dalam menrapkan protokol kesehatan di masa pandemi COVID-19. Analisis bivariat menggunakan uji spearman rank. Penelitian ini uji normalitas tidak dilakukan karena data pada penelitian ini menggunakan skala ordinal yang bersifat non parametrik, sehingga penelitian ini langsung menggunakan uji korelasi spearman $\operatorname{rank}^{(10)}$. 
Putu Maya Oktavianti, N.L.K.Sulisnadewi, Ida Erni Sipahutar. Desember

2021. 14 (2): 67-82

Penelitian ini sudah dilakukan uji etika Peneltian dengan nomor surat LB.02.03/EA/KEPK/0164/2021

\section{HASIL DAN PEMBAHASAN}

Tabel 1. Distribusi Frekuensi KarakteristikResponden Berdasarkan Umur dan Jenis Kelamin di SMP Negeri 10 Denpasar Tahun 2021

\begin{tabular}{lcc}
\hline Karakteristik Responden & Frekuensi (n) & Persentase (\%) \\
\hline Umur Responden & 0 & \\
11 & 14 & 0,0 \\
12 & 39 & 15,6 \\
13 & 37 & 43,3 \\
14 & 0 & 41,1 \\
15 & & 0,0 \\
Jenisi Kelamin & 42 & \\
Laki-laki & 48 & 46,7 \\
Perempuan & 90 & 53,3 \\
\hline Jumlah & & 100 \\
\hline
\end{tabular}

Hasil penelitian tabel 1 menunjukkan sebagian besar responden berumur 13 tahun yang berada pada kategori remaja awal yakni berumur 12-15 tahun yakni sebanyak 39 responden (43,3\%). Hasil penelitian ini selaras dengan penelitian di SMP Negeri 2 Ponorogo, yang menyatakan sebagian besar remaja berumur 13 tahun sebanyak 31 responden $(72,1 \%)$. Penelitian ini mayoritas responden berjenis kelamin perempuan sebanyak 48 responden $(53,3 \%)^{(11)}$. Hasil penelitian ini selaras dengan penelitian di Desa Mahayan, yang menyatakan sebanyak 40 responden $(54,1 \%)$ berjenis kelamin perempuan. Hal ini sesuai dengan data sekunder yang didapat dari SMP Negeri 10 Denpasar bahwa siswa perempuan lebih banyak dari siswa laki - laki ${ }^{(12)}$.

Umur mempengaruhi mentalitas remaja, dengan bertambahnya umur cara pandang remaja menjadi luas, sehingga pengetahuan yang didapat semakin baik. Usia dikelompokkan menjadi remaja awal (12-15 tahun), remaja pertengahan (1518 tahun) dan remaja akhir (18-21 tahun. Masa remaja awal (12-15 tahun), adalah fase yang mendasari perubahan cepat pada remaja baik secara fisik maupun 
Putu Maya Oktavianti, N.L.K.Sulisnadewi, Ida Erni Sipahutar. Desember 2021. 14 (2): 67-82

mental. Minat remaja terhadap sesuatu yang baru sangat besar sehingga memudahkan remaja untuk menyimpan informasi yang diperoleh ${ }^{(13)}$.

Remaja perempuan dan remaja laki - laki mempunyai berbagai tingkat kesadaran akan pentingnya informasi tentang COVID-19. Umumnya remaja lakilaki mempunyai tingkat kesadaran yang lebih rendah dibandingkan dengan remaja perempuan sehingga akan bersikap seakan tidak peduli.

Tabel 2. Sebaran Item Pertanyaan Tingkat Pengetahuan Remaja Tentang COVID19 di SMP Negeri 10 Denpasar Tahun 2021

\begin{tabular}{llll}
\hline No & Item & $\begin{array}{l}\text { Benar } \\
(\mathbf{f} / \%)\end{array}$ & $\begin{array}{c}\text { Salah } \\
(\mathbf{f} / \%)\end{array}$ \\
\hline 1 & TP1 & $(79 / 87.8)$ & $(11 / 12.2)$ \\
2 & TP2 & $(70 / 77.8)$ & $(20 / 22.2)$ \\
3 & TP3 & $(86 / 95.6)$ & $(4 / 4.4)$ \\
4 & TP4 & $(87 / 96.7)$ & $(3 / 3.3)$ \\
5 & TP5 & $(6 / 6.7)$ & $(84 / 93.3)$ \\
6 & TP6 & $(76 / 84.4)$ & $(14 / 15.6)$ \\
7 & TP7 & $(74 / 82.2)$ & $(16 / 17.8)$ \\
8 & TP8 & $(82 / 91.1)$ & $(8 / 8.9)$ \\
9 & TP9 & $(82 / 91.1)$ & $(8 / 8.9)$ \\
10 & TP10 & $(90 / 100.0)$ & $(0 / 0.0)$ \\
11 & TP11 & $(89 / 98.9)$ & $(1 / 1.1)$ \\
12 & TP12 & $(89 / 98.9)$ & $(1 / 1.1)$ \\
13 & TP13 & $(89 / 98.9)$ & $(1 / 1.1)$ \\
14 & TP14 & $(86 / 95.6)$ & $(4 / 4.4)$ \\
15 & TP15 & $(81 / 90.0)$ & $(9 / 10.0)$ \\
\hline
\end{tabular}

Tabel 3. Distribusi Frekuensi Responden Berdasarkan Tingkat Pengetahuan Remaja Tentang COVID-19 di SMP Negeri 10 Denpasar Tahun 2021

\begin{tabular}{cccc}
\hline No & Tingkat Pengetahuan & Frekuensi (n) & Persentase (\%) \\
\hline 1 & Baik & 80 & 88,9 \\
2 & Cukup & 10 & 11,1 \\
3 & Kurang & 0 & 0,0 \\
\hline Jumlah & & 90 & 100 \\
\hline
\end{tabular}


Putu Maya Oktavianti, N.L.K.Sulisnadewi, Ida Erni Sipahutar. Desember 2021. 14 (2): 67-82

Tabel 4. Sebaran Tingkat Pengetahuan Remaja Tentang Covid-19 Berdasarkan Karaktersitik Umur dan Jenis Kelamin di SMP Negeri 10 Denpasar Tahun 2021.

\begin{tabular}{llcccc}
\hline No & Karakteristik & $\begin{array}{c}\text { Baik } \\
(\mathrm{F} / \%)\end{array}$ & $\begin{array}{c}\text { Cukup } \\
(\mathrm{F} / \%)\end{array}$ & $\begin{array}{c}\text { Kurang } \\
(\mathrm{F} / \%)\end{array}$ & $\begin{array}{c}\text { Total } \\
(\mathrm{F} / \%)\end{array}$ \\
\hline 1 & Usia & & & & \\
& $\begin{array}{l}\text { Remaja awal } \\
\text { Remaja }\end{array}$ & $(80 / 88.9 \%)$ & $(10 / 11.1 \%)$ & $(0 / 0 \%)$ & $(90 / 100.0 \%)$ \\
& $\begin{array}{l}\text { tengah } \\
\text { Remaja }\end{array}$ & $(0 / 0 \%)$ & $(0 / 0 \%)$ & $(0 / 0 \%)$ & $(0 / 0 \%)$ \\
& $\begin{array}{l}\text { akhir } \\
\text { Seks }\end{array}$ & & $(0 / 0 \%)$ & $(0 / 0 \%)$ & $(0 / 0 \%)$ \\
& $\begin{array}{l}\text { Laki-laki } \\
\text { Perempuan }\end{array}$ & $(34 / 81.0 \%)$ & $(8 / 19.0 \%)$ & $(0 / 0 \%)$ & $(42 / 100.0 \%)$ \\
\hline
\end{tabular}

Hasil penelitian tabel 3 menunjukkan remaja dengan tingkat pengetahuan baik sebanyak 80 responden $(88,9 \%)$, tingkat pengetahuan cukup sebanyak 10 responden $(11,1 \%)$ dan tidak ada yang memiliki tingkat pengetahuan kurang. Hasil yang didapatkan menunjukkan bahwa sebagian besar tingkat pengetauan remaja tentang COVID-19 berkategori baik. Hasil penelitian ini selaras dengan penelitian di Desa Mayahan yang berjudul Tingkat Pengetahuan Remaja Tentang Covid-19 didapatkan bahwa sebagian besar remaja memiliki tingkat pengetahuan baik sebanyak 54 responden $(74,32 \%)$ dari 74 responden $^{(15)}$. Hasil penelitian lain menunjukkan hal yang sama dengan penelitian (Purnamasari and Raharyani, 2020) di Kabupaten Wonosobo yang berjudul Tingkat Pengetahuan Dan Perilaku Masyarakat Kabupaten Wonosobo Tentang Covid-19 didapatkan sebagian besa tingkat pengetahuan yang dimiliki mahasiswa berkategori baik sebanyak 130 responden $(90,3 \%)$ dari 144 responden.

Pengetahuan merupakan hasil dari indra yang dimiliki remaja maupun hasil tahu terhadap suatu objek tertentu. Pada waktu pengindraan dengan sendirinya akan membuat pengetahuan mempengaruhi kekuatan pertimbangan dan kesan terhadap objek tersebut. Pengetahuan remaja sebagian besar dipengaruhi oleh indra penglihatan dan indra pendengaran ${ }^{(17)}$.

Terdapat beberapa komponen yang mempengeruhi tingkat pengetahuan remaja seperti pendidikan, umur, Informasi/media massa, dan pengalaman. 
Informasi tentang COVID-19 bisa didapatkan remaja melalui media social, internet, televisi, kementrian kesehatan, WHO dan informasi dari teman sebaya $^{(19)}$. Jika remaja mendapatkan lebih banyak informasi tentang sesuatu, mereka pada umunya akan mempunyai pengetahuan yang lebih luas. Pendidikan adalah salah satu komponen yang mempengaruhi pengetahuan remaja, responden saat ini pendidikan telah sampai pada tingkat SMP. Semakin tingginya tingkat pendidikan remaja maka akan semakin banyak pengetahuan yang akan mereka peroleh. Umur menjadi salah satu elemen yang mempengaruhi daya tangkap remaja dalam memperoleh informasi serta pengetahuan ${ }^{(20)}$. Semakin bertambah umur remaja maka akan semakin dewasa sikap remaja tersebut, oleh karena itu secara tidak langsung pengetahuan remaja akan bertambah. Pengalaman juga mempengaruhi pengetahuan remaja, pengalaman berperan penting dalam mengajarkan remaja dalam berpikir dan bertindak sesuai dengan apa yang telah terjadi sebelumnya, jika remaja mempunyai pengalaman yang sedikit maka pengetahuan yang dimiliki juga akan sedikit.

Menurut pendapat peneliti, sebagian besar tingkat pengetahuan remaja berkategori baik karena remaja sering melihat maupun mendengar melalui internet maupun televisi tentang COVID-19, begitu pula dalam segi umur remaja SMP sangat mudah untuk mengingat apa yang sudah pernah didengar maupun dilihat sebelum nya. Informasi tentang COVID-19 yang didapat remaja sangat berpengaruh terhadap tingkat pengetahuan remaja tentang COVID-19, semakin banyak informasi yang didapat remaja tentang COVID-19 maka semakin baik tingkat pengetahuan remaja, sebaliknya bila semakin sedikit informasi yang diperoleh remaja tentang COVID-19 maka tingkat pengetahuan remaja kurang. 
Putu Maya Oktavianti, N.L.K.Sulisnadewi, Ida Erni Sipahutar. Desember 2021. 14 (2): 67-82

Tabel 5. Sebaran Item Pertanyaan Sikap Remaja Dalam Menerapkan Protokol Kesehatan Di Masa Pandemi COVID-19 di SMP Negeri 10 Denpasar Tahun 2021

\begin{tabular}{llllll}
\hline No & Item & $\begin{array}{c}\text { Sangat Setuju } \\
(\mathrm{F} / \%)\end{array}$ & $\begin{array}{c}\text { Setuju } \\
(\mathrm{F} / \%)\end{array}$ & $\begin{array}{r}\text { Tidak } \\
\text { Setuju } \\
(\mathrm{F} / \%)\end{array}$ & $\begin{array}{c}\text { Sangat } \\
\text { Tidak Setuju } \\
(\mathrm{F} / \%)\end{array}$ \\
\hline 1 & $\mathrm{~S} 1$ & $(42 / 46.7)$ & $(39 / 43.3)$ & $(8 / 8.9)$ & $(1 / 1.1)$ \\
2 & $\mathrm{~S} 2$ & $(78 / 86.7)$ & $(12 / 13.3)$ & $(0 / 0.0)$ & $(0 / 0.0)$ \\
3 & $\mathrm{~S} 3$ & $(78 / 86.7)$ & $(12 / 13.3)$ & $(0 / 0.0)$ & $(0 / 0.0)$ \\
4 & $\mathrm{~S} 4$ & $(74 / 82.2)$ & $(15 / 16.7)$ & $(1 / 1.1)$ & $(0 / 0.0)$ \\
5 & $\mathrm{~S} 5$ & $(81 / 90.0)$ & $(9 / 10.0)$ & $(0 / 0.0)$ & $(0 / 0.0)$ \\
6 & $\mathrm{~S} 6$ & $(77 / 85.6)$ & $(13 / 14.4)$ & $(0 / 0.0)$ & $(0 / 0.0)$ \\
7 & $\mathrm{~S} 7$ & $(67 / 74.4)$ & $(23 / 25.6)$ & $(0 / 0.0)$ & $(0 / 0.0)$ \\
8 & $\mathrm{~S} 8$ & $(75 / 83.3)$ & $(14 / 15.6)$ & $(1 / 1.1)$ & $(0 / 0.0)$ \\
9 & $\mathrm{~S} 9$ & $(75 / 83.3)$ & $(15 / 16.7)$ & $(0 / 0.0)$ & $(0 / 0.0)$ \\
10 & $\mathrm{~S} 10$ & $(57 / 63.3)$ & $(27 / 30.0)$ & $(6 / 6.7)$ & $(0 / 0.0)$ \\
11 & $\mathrm{~S} 11$ & $(56 / 62.2)$ & $(32 / 35.6)$ & $(2 / 2.2)$ & $(0 / 0.0)$ \\
12 & $\mathrm{~S} 12$ & $(61 / 67.8)$ & $(29 / 32.2)$ & $(0 / 0.0)$ & $(0 / 0.0)$ \\
13 & $\mathrm{~S} 13$ & $(65 / 72.2)$ & $(24 / 26.7)$ & $(1 / 1.1)$ & $(0 / 0.0)$ \\
14 & $\mathrm{~S} 14$ & $(3 / 3.3)$ & $(5 / 5.6)$ & $(31 / 34.4)$ & $(51 / 56.7)$ \\
15 & $\mathrm{~S} 15$ & $(7 / 7.8)$ & $(5 / 5.6)$ & $(31 / 34.4)$ & $(47 / 52.2)$ \\
16 & $\mathrm{~S} 16$ & $(1 / 1.1)$ & $(1 / 1.1)$ & $(26 / 28.9)$ & $(62 / 68.9)$ \\
17 & $\mathrm{~S} 17$ & $(2 / 2.2)$ & $(0 / 0.0)$ & $(21 / 23.3)$ & $(67 / 74.4)$ \\
18 & $\mathrm{~S} 18$ & $(63 / 70.0)$ & $(18 / 20.0)$ & $(3 / 3.3)$ & $(6 / 6.7)$ \\
19 & $\mathrm{~S} 19$ & $(1 / 1.1)$ & $(1 / 1.1)$ & $(1 / 1.1)$ & $(73 / 81.1)$ \\
\hline
\end{tabular}

Tabel 6. Distribusi Frekuensi Responden Berdasarkan Sikap Remaja Dalam Menerapkan Protokol Kesehatan Di Masa Pandemi COVID-19 di SMP Negeri 10 Denpasar Tahun 2021

\begin{tabular}{cccc}
\hline No & Sikap & Frekuensi (n) & Persentase (\%) \\
\hline 1 & Positif & 76 & 84,4 \\
2 & Negatif & 14 & 15,6 \\
\hline & Jumlah & 90 & 100 \\
\hline
\end{tabular}


Putu Maya Oktavianti, N.L.K.Sulisnadewi, Ida Erni Sipahutar. Desember 2021. 14 (2): 67-82

Tabel 7. Sebaran Sikap Remaja Dalam Menerapkan Protokol Kesehatan Di Masa Pandemi COVID-19 di SMP Negeri 10 Denpasar Tahun 2021 Berdasarkan Karaktersitik Umur dan Jenis Kelamin di SMP Negeri 10 Denpasar Tahun 2021.

\begin{tabular}{llccc}
\hline No & Karakteristik & $\begin{array}{c}\text { Positif } \\
(\mathbf{F} / \%)\end{array}$ & $\begin{array}{c}\text { Negatif } \\
(\mathbf{F} / \%)\end{array}$ & $\begin{array}{c}\text { Total } \\
(\mathbf{F} / \%)\end{array}$ \\
\hline 1 & Usia & & & \\
& Remaja awal & $(76 / 84.4 \%)$ & $(14 / 15.6 \%)$ & $(90 / 100.0 \%)$ \\
& $\begin{array}{l}\text { Remaja } \\
\text { tengah }\end{array}$ & $(0 / 0 \%)$ & $(0 / 0 \%)$ & $(0 / 0 \%)$ \\
& Remaja akhir & $(0 / 0 \%)$ & $(0 / 0 \%)$ & $(0 / 0 \%)$ \\
2 & Seks & $(30 / 71.4 \%)$ & $(12 / 28.6 \%)$ & $(42 / 100.0 \%)$ \\
& Laki-laki & $(46 / 95.8 \%)$ & $(2 / 4.2 \%)$ & $(48 / 100.0 \%)$ \\
\hline
\end{tabular}

Tabel 7 menunjukkan remaja dengan sikap positif sebanyak 76 responden $(84,4 \%)$ dan remaja dengan sikap negatif sebanyak 14 responden $(15,6 \%)$. Berdasarkan hasil yang diperoleh menunjukkan bahwa sebagian besar sikap remaja dalam menerapkan protokol kesehatan di masa pandemi COVID-19 berkategori positif. Hasil penelitian selaras dengan penelitian di Provinsi DKI Jakarta yang berjudul Pengetahuan, Sikap Dan Keterampilan Masyarakat Dalam Pencegahan COVID-19 didapatkan bahwa sebagian besar responden mempunyai sikap yang baik sebanyak 722 responden dari 1021 responden ${ }^{(6)}$. Hasil penelitian selaras dengan penelitian di Desa Murtajih yang berjudul Pengetahuan Dan Sikap Masyarakat Dalam Pencegahan Covid-19 didapatkan bahwa sebagian besar sikap masyarakat memiliki sikap positif sebanyak 53 responden dari 62 responden ${ }^{(21)}$.

Sikap adalah respon individu terhadap suatu stimulus. Sehingga sikap remaja dalam penelitian ini dapat di artikan sebagai respon remaja terhadap kejadian COVID-19. Terdapat beberapa komponen yang mempengaruhi sikap remaja seperti media masa, pengalaman pribadi, budaya, pengaruh orang lain, agama, lembaga pendidikan, dan emosi ${ }^{(13)}$. Semakin tinggi pengetahuan remaja maka akan semakin positif sikap remaja tersebut, sebaliknya kurangnya pengetahuan remaja akan menunjuukan sikap negatif. Pengalaman remaja dapat mempengaruhi terbentuknya sikap remaja terhadap suatu objek tertentu. Pengaruh orang lain yang amat dianggap penting atau seseorang yang istimewa akan sangat mempengaruhi remaja. Terbentuknya sikap remaja tersebut sebab adanya interaksi 
Putu Maya Oktavianti, N.L.K.Sulisnadewi, Ida Erni Sipahutar. Desember 2021. 14 (2): 67-82

yang dialami oleh remaja, seperti ada pengaruh dari teman sebaya, guru maupun orang tua. Budaya juga mempengaruhi terbentuknya sikap remaja, dimana budaya mempunyai peran yang utama dalam hal ini. Informasi yang di peroleh remaja adalah hasil dari penggabungan terhadap informasi serta keyakinan yang pada remaja, sehingga sikap ditentukan oleh seberapa baik penggabungan remaja untuk menyaring informasi mana yang benar maupun mana yang tidak benar ${ }^{(23)}$. Penelitian ini faktor yang mempengaruhi sikap dilihat dari faktor pengetahuan.

Menurut pendapat peneliti, remaja yang mempunyai sikap negatif disebabkan remaja lebih sering mengabaikan informasi yang beredar tentang protokol kesehatan maka pengetahuan yang dimilikinya kurang, sehingga berpengaruh terhadap sikap remaja dalam menerapkan protokol kesehatan. Remaja menganggap COVID-19 tidak ada dan masalah yang biasa, sehingga remaja mengabaikan pencegahan COVID-19. Jika sikap remaja positif maka semakin rendah terjadinya penularan COVID-19.

Tabel 8. Analisis Bivariat Hubungan Tingkat Pengetahuan Remaja Tentang COVID-19 Dengan Sikap Remaja Dalam Menerapkan Protokol Kesehatan Di Masa Pandemi COVID-19

\begin{tabular}{|c|c|c|c|c|c|c|c|c|}
\hline \multirow[t]{3}{*}{ Tingkat Pengetahuan } & \multicolumn{4}{|c|}{ Sikap } & \multirow{2}{*}{\multicolumn{2}{|c|}{ Total }} & \multirow{3}{*}{$r$} & \multirow[b]{2}{*}{$p$} \\
\hline & \multicolumn{2}{|c|}{ Positif } & \multicolumn{2}{|c|}{ Negatif } & & & & \\
\hline & $\mathrm{n}$ & $\%$ & $\mathrm{n}$ & $\%$ & $\mathrm{n}$ & $\%$ & & \multirow{4}{*}{0,000} \\
\hline Baik & 75 & 93,8 & 5 & 6,3 & 80 & 100,0 & \multirow{3}{*}{0,726} & \\
\hline Cukup & 1 & 10,0 & 9 & 90,0 & 10 & 100,0 & & \\
\hline Kurang & 0 & 0,0 & 0 & 0,0 & 0 & 0,0 & & \\
\hline Total & 76 & 84,4 & 14 & 15,6 & 90 & 100,0 & & \\
\hline
\end{tabular}

Tabel 8 menunjukkan tingkat pengetahuan baik dengan sikap positif sebanyak 75 (93,8\%), tingkat pengetahuan cukup dengan sikap positif sebanyak 1 $(10,0 \%)$, serta tidak ditemukan remaja dengan tingkat pengetahuan kurang dengan sikap positif, tingkat pengetahuan baik dengan sikap negatif sebanyak $5(6,3 \%)$, tingkat pengetahuan cukup dengan sikap negatif sebanyak $9(90,0 \%)$ serta tidak ditemukan remaja dengan tingkat pengetahuan kurang dengan sikap negatif.

Hasil analisis bivariat yang menggunakan uji spearman rank diperoleh nilai $p$ value 0.000 lebih kecil 0.05 maka Ho ditolak, Ha diterima artinya terdapat 
hubungan tingkat pengetahuan remaja tentang COVID-19 dengan sikap remaja dalam menerapkan protokol kesehatan di masa pandemi COVID-19. Kuat rendahnya korelasi dilihat dari nilai $\mathrm{r}$ yaitu 0,726 . Nilai tersebut menunjukkan korelasi yang kuat antara variabel tingkat pengetahuan remaja tentang COVID-19 dengan sikap remaja dalam menerapkan protokol kesehatan di masa pandemi COVID-19. Nilai koefisien korelasi bertanda positif menunjukkan bahwa semakin baik tingkat pengetahuan remja tentang COVID-19 maka semakin positif sikap remaja dalam menerapkan protokol kesehatan di masa pandemi COVID-19.

Hal tersebut mengungkapkan semakin baik tingkat pengetahuan maka semakin positif sikap remaja. Sikap remaja terhadap suatu objek tertentu akan menunjukkan tingkat pengetahuan remaja terhadap objek yang dimaksud. Dapat diuraikan bahwa sikap positif maupun sikap negatif terbentuk dari tingkat pengetahuan, pengetahuan yang didapat semakin luas maka akan semakin positif sikap terbentuk, semakin tahu tentang COVID-19 maka sikap remaja dalam menerapkan protokol kesehatan juga semakin positif. Jadi terdapat hubungan tingkat pengetahuan remaja terhadap sikap remaja ${ }^{(13)}$.

Hasil Penelitian ini selaras dengan penelitian yang berjudul a cros sectional survey of knowledge, attitudes and practices related to COVID-19 among undergraduate students in China, yang menunjukkan sebanyak 80 orang tingkat pengetahuan baik dan sebanyak 79 orang dengan sikap positif ${ }^{(24)}$. Hasil penelitian ini selaras dengan penelitian yang berjudul Pengetahuan Dan Sikap Mahasiswa Kesehatan Tentang Pencegahan Covid-19 Di Indonesia didapatkan pengetahuan baik sebanyak 288 sedangkan sikap positif sebanyak $206^{(25)}$.

Hasil penelitian ini selaras dengan penelitian yang berjudul Pengetahuan dengan Sikap Pencegahan Covid-19 pada Masyarakat Sulawesi Utara menunjukkan terdapat hubungan antara pengetahuan dengan sikap pencegahan Covid- 19 pada masyarakat Sulawesi Utara dengan nilai $\mathrm{p}=0,000^{(26)}$.

\section{SIMPULAN}

Karakteristik responden yang memiliki umur terbanyak yaitu umur 13 tahun dengan persentase $43,3 \%$, jenis kelamin terbanyak yaitu jenis kelamin 
Putu Maya Oktavianti, N.L.K.Sulisnadewi, Ida Erni Sipahutar. Desember

2021. 14 (2): 67-82

perempuan dengan persentase 53,3\%. Tingkat pengetahuan remaja tentang COVID-19 berkategori baik 88,9\%, tingkat pengetahuan cukup 11,1\%, serta tidak ada yang memiliki tingkat pengetahuan kurang. Sikap remaja dalam menerapkan protokol kesehatan di masa pandemi COVID-19 berkategori positif 84,4\%, dan remaja dengan sikap negatif $15,6 \%$. Terdapat hubungan tingkat pengetahuan remaja tentang COVID-19 dengan sikap remaja dalam menerapkan protokol kesehatan di masa pandemi COVID-19 dengan nilai $\mathrm{p}=0,000$. Nilai $\mathrm{r}=0,726$ menunjukkan korelasi yang kuat antara variabel tingkat pengetahuan dengan sikap dan arah hubungannya bersifat positif yang artinya semakin baik tingkat pengetahuan remja tentang COVID-19 maka semakin positif sikap remaja dalam menerapkan protokol kesehatan di masa pandemi COVID-19.

\section{UCAPAN TERIMAKASIH}

Terimakasih kepada institusi Poltekkes Denpasar, SMP Negeri 10 denpasar, dosen pembimbing, keluarga dan semua orang yang terkait dalam penelitian ini yang tidak bisa disebutkan satu per satu.

\section{ETHICAL CLEARENCE}

Etika Peneltian ini diperoleh dari Politeknik Kesehatan Kementerian Kesehatan Denpasar. Dengan nomor surat LB.02.03/EA/KEPK/0164/2021

\section{DAFTAR RUJUKAN}

1. Sutaryo, Yang N, Sagoro L, Sabrina DS. Buku Praktis Penyakit Virus Corona 19 (COVID-19). irfan, editor. Yogyakarta: Gadjah Mada University Press; 2020.

2. WHO. weekly epidemiological update. 2021.

3. Komite Penanganan Covid-19 dan Pemulihan Ekonomi Nasional. Peta Sebaran COVID-19. Satuan Tugas Penanganan COVID-19. 2021.

4. BPBD Kota Denpasar. Mitigasi Covid 19 \& DBD Di Kota Denpasar. Badan Penanggulangan Bencana Daerah. 2021.

5. CDC COVID-19. Coronavirus Disease 2019 in Children - United States ,. CDC COVID-19 Response Team. 2020;69(14).

6. Utami RA, Mose RE, Martini M. Pengetahuan, Sikap dan Keterampilan Masyarakat dalam Pencegahan COVID-19 di DKI Jakarta. J Kesehat Holist. 2020;4(2). 
7. Habibie nur. UNICEF Survei 4.000 Remaja Terkait Covid-19, 70 Persen Percaya Langkah Pemerintah. merdeka.com. 2020.

8. CNN Indonesia. Unicef:40 Persen Remaja di RI Masih Keluyuran. cnnindonesia.com. 2020.

9. Nursalam. Metodologi Penelitian Ilmu keperawatan. Jakarta: Salemba Medika; 2017.

10. Sugiyono. Metode Penelitian Kuantitatif, Kualitatif, dan R\&D. 2nd ed. Bandung: Alfabeta; 2019.

11. Ardiati AN, Ernawati H, Purwanti LE. Hubungan Pengetahuan Dengan Perilaku Personal Hygiene Saat Menstruasi Pada Remaja Putri Di SMP 2 Ponorogo. Pros Semin Nas dan Call Pap. 2019;

12. Untari S, Himawati L. Tingkat Pengetahuan Remaja Tentang COVID-19 Di Desa Mayahan. Univ An Nuur Purwodadi. 2019;8(5).

13. Wawan, A dan Dewi M. Teori \& Pengukuan Pengetahuan, Sikap, dan Prilaku Manusia. Yogyakarta: Nuha Medika.; 2018.

14. Ahyani LN, Kudus UM, Kudus UM. Buku Ajar Psikologi Perkembangan Anak dan Remaja. Kudus: Universitas Muria Kudus; 2018.

15. Djawa YD, Hariyanto T, Ardiyani VM. Hubungan Tingkat Pengetahuan Dengan Perilaku Membuang Sampah pada Siswa SMP Sriwedari Malang. Nurs News (Meriden). 2017;2(2).

16. Juliana MI, Rahmayanti MD, Astika ME. Tingkat Pengetahuan Dan Sikap Siswa SMP Tentang Kesehatan Reproduksi Remaja Berdasarkan Keikutsertaan Pada Program Pusat Informasi Dan Konseling-Remaja (PikR). Dunia Keperawatan. 2018;6(2).

17. Purnamasari I, Raharyani2 AE. Tingkat Pengetahuan Dan Perilaku Masyarakat Kabupaten Wonosobo Tentang COVID-19. Dosen Keperawatan FIKES UNSIQ Wonosobo. 2020;3(1).

18. Mertha IM, Ribek IN, Widastra IM. Kelompok Swabntu Diabetes Terhadap Pengetahuan Dan Kepatuhan Kontrol Pasien Diabetes Mellitus. Jur Keperawatan Politek Kesehat Denpasar. 2016;

19. Puspitasari IM, Yusuf L, Sinuraya RK, Abdulah R, Koyama H. Knowledge , Attitude, and Practice During the COVID-19 Pandemic : A Review. 2020;

20. Mamba S. Hubungan Usia Dengan Pengetahuan Remaja Putri Tentang Pemeriksaan Payudara Sendiri ( SADARI ) Age Relationship With The Adolecent Knowledge Of The Principles About The Significant Breast Treatment ( BSE ) Hubungan Usia Dengan Pengetahuan Remaja Putri Tent. 2017;

21. Suprayitno E et. al. Pengetahuan dan Sikap Masyarakat dalam Pencegahan COVID-19. J Heal Sci (Jurnal Ilmu Kesehatan). 2020;5(1).

22. Aulia N, Winarti Y. Hubungan Peran Teman Sebaya dengan Perilaku Seks Bebas pada Remaja di SMA Negeri 16 Samarinda. Borneo Student Res. 2020;1(3).

23. Komariah ED, Beda NS. The Relationship Between Knowledge Level And Youth Attitudes Towards Drug. 2020;7(2).

24. Peng Y, Pei C, Zheng Y, Wang J, Zhang K, Zheng Z, et al. Knowledge, Attitude and Practice Associated with COVID-19 among University 
Putu Maya Oktavianti, N.L.K.Sulisnadewi, Ida Erni Sipahutar. Desember 2021. 14 (2): 67-82

Students: a Cross-Sectional Survey in China. 2020;

25. Usman S, Budi S, Nur Adkhana Sari D. Pengetahuan Dan Sikap Mahasiswa Kesehatan Tentang Pencegahan Covid-19 Di Indonesia. J Ilmu Keperawatan dan Kebidanan. 2020;11(2).

26. Sembiring EE, Nena Meo ML. Pengetahuan dan Sikap Berhubungan dengan Resiko Tertular Covid-19 pada Masyarakat Sulawesi Utara. NERS J Keperawatan. 2020;16(2). 